\title{
Self-Efficacy in Computer-Based Learning Environments: A Bibliometric Analysis*
}

\author{
Nilson Valencia-Vallejo, Omar López-Vargas, Luis Sanabria-Rodríguez \\ Departamento de Tecnología, Universidad Pedagógica Nacional, Bogotá, Colombia \\ Email: nvalencia@pedagogica.edu.co
}

How to cite this paper: Valencia-Vallejo, N., López-Vargas, O., \& Sanabria-Rodríguez, L. (2016). Self-Efficacy in Computer-Based Learning Environments: A Bibliometric Analysis. Psychology, 7, 1839-1857. http://dx.doi.org/10.4236/psych.2016.714170

Received: October 29, 2016

Accepted: December 2, 2016

Published: December 5, 2016

Copyright $\odot 2016$ by authors and Scientific Research Publishing Inc. This work is licensed under the Creative Commons Attribution International License (CC BY 4.0).

http://creativecommons.org/licenses/by/4.0/

\begin{abstract}
The objective of the present study is to describe and analyze the state of research on the self-efficacy construct and its association with learning in computational environments based on the review of articles published in journals during the period between 2006 and 2015. To conduct the study, the Science Direct, Scopus, and SciELO databases were used and a bibliometric analysis was performed. Eighty-one (81) published scientific texts from 31 journals were analyzed. Most academic productivity on the subject matter came from Asian countries. A predominance of correlational studies was found. A total of 62 questionnaires to evaluate participants' self-efficacy in domains associated with Information and Communications Technologies (ICT) were found. The self-efficacy subscale of the Motivated Strategies for Learning Questionnaire (MSLQ) is used the most by researchers. It is possible to conclude that self-efficacy is a predictor of students' successful performance in computational environments, which, in turn, influences other variables that allow better attitudes in learning. Self-efficacy has positioned itself as a current and interesting subject matter, which is why e-learning designers and educators must pay attention to the contributions derived from research in order to put them into practice.
\end{abstract}

\section{Keywords}

Self-Efficacy, Computer Aided Learning, Information Technologies, Internet, Bibliometrics

\section{Introduction}

In recent years, the study of self-efficacy, a psychological notion that is significantly related to students' learning in traditional and computational environments, has gained importance. In an ICT in education context, self-efficacy has become a varia-

\footnotetext{
${ }^{\star}$ This article represents a contribution to the first author's doctoral thesis.
} 
ble of interest since studies show that it is positively associated with: academic performance (López \& Triana, 2013), learning strategy choice and its results (Moos \& Azevedo, 2009), individuals' expectations and their emotional reaction (Bates \& Khasawneh, 2007), learning goal formulation (López, Ibáñez, \& Chiguasuque, 2014), and favorable behaviors and attitudes towards learning (Torkzadeh, Chang, \& Demirhan, 2006).

The present study has the purpose of describing and analyzing the state of research of the self-efficacy construct and its association with learning in computational environments based on the elaboration of a bibliometric study. To that end, three databases were selected, the first two of academic prestige in Anglo-Saxon literature, Science Direct and Scopus, and the third, SciELO, is a free access database of academic prestige in Ibero-America, and their publications corresponding to the period between 2006 and 2015 were analyzed.

Among the study's purposes, are to seek a scientific production approach to the subject matter in question and contribute quantitative data on the state of the publications, describe and evaluate the scientific activity and its authors, identify the domains of knowledge that explore the variables object of study, the types of research and methodological approaches, the populations involved, types of digital technologies used, and the information gathering instruments that are most employed (Valencia, Huertas, \& Baracaldo, 2014).

In accordance with the foregoing, the intent is to present quantitative and qualitative data that may be used as an investigative and/or practical point of reference, and that at the same time, allow orienting research studies in the ICT field, which permit a better understanding of this psychological notion and its relationship with the man-computer interaction within an educational process framework.

\section{Literature Review}

\subsection{Self-Efficacy}

The notion of self-efficacy is defined as the judgements that a subject makes on their own abilities to organize and execute courses of action necessary to achieve different objectives (Bandura, 1986, 1989). Many factors exist that determine human behavior; Bandura (1997) identifies self-efficacy as an important mechanism that influences both individuals' performance in task execution and cognitive processing. In accordance with the foregoing, it is possible to assert that the mental construction that individuals make of their own self-efficacy has a variety of distinctive characteristics. These are important because they allow distinguishing it from other psychological notions; additionally, these include implication on how self-efficacy should be measured.

In the first place, self-efficacy has specific attributes through activities and contexts, which are: level, generality, and strength. Level refers to the difficulty of one task in particular, generality refers to the transference of the beliefs of self-efficacy of one task to another, and strength is determined by the amount of certainty that the individual has to successfully complete a determined task (Bandura, 1989). In the second place, 
self-efficacy beliefs are not a unique disposition, they are multidimensional in form and differ on the level of the task or domain (Schunk, 1991). In the third place, regarding content, self-efficacy measures are focused on subjects' performance or abilities more than on personal qualities, such as physical development or psychological characteristics (Bandura, 1986).

Bandura posits the existence of four main sources of information that determine individuals' self-efficacy: domain experiences, vicarious experiences, verbal persuasion and social influence, and physiological states (Bandura, 1986: p. 424). Of the four sources, domain experiences are the most effective way of creating a strong sense of self-efficacy (Bandura, 1997). These refer to the interpretations that individuals make of their past actions and they contribute the most authentic proof of the abilities possessed to successfully achieve the development of a learning task (Usher \& Pajares, 2009). The second source of self-efficacy are vicarious experiences or indirect experiences. "Viewing or imagining that other similar individuals act successfully, possibly increases the observer's self-perception of self-efficacy, coming to believe that they themselves also possess the abilities" (Bandura, 1986: p. 425). Indirect experiences are not as strong as domain experiences, however, these can produce significant and lasting changes in self-efficacy through their effect on performance (Bandura, 1986).

Verbal persuasion and social influence is the third source of self-efficacy. It is used to induce individuals into believing that they are capable of reaching the objective laid out. Individuals that are convinced verbally by others that they possess the ability to carry out the tasks are susceptible of mobilizing a greater effort and maintaining it when faced with difficulties (Schunk, 1991). The last source of self-efficacy are the physiological states. Levels of moderate physiological activation (sweating, agitation, fatigue, etc.) will facilitate the deployment of abilities, while an elevated activation will influence the levels of self-efficacy.

\subsection{Self-Efficacy in Computational Environments}

In recent decades, an important number of studies have developed around self-efficacy in the field of ICT and education. In fact, diverse research has examined this notion from different perspectives according to Bandura (1997), who asserts that self-efficacy beliefs can be specified in the level of the task or domain. In accordance with this, and before presenting the results of the bibliometric study, it is convenient to identify the different fields of study of self-efficacy in association with ICT as a domain, which are found in the research that are analyzed in the present study.

The first field of study, academic self-efficacy, has been the object of study during the execution of learning tasks in computational scenarios (Jan, 2015). It refers to students' perception of their ability to complete academic tasks in these scenarios (Girasoli \& Hannafin, 2008). Research reveal that students with high academic self-efficacy participate more actively in educational activities, make more of an effort, and can develop effective strategies when obstacles arise (Odaci, 2013). It is noteworthy to mention that the factors that influence individuals' AS derive from both the computational learning 
environment and the topic of study (Moos \& Azevedo, 2008).

The second field of study, computer self-efficacy, arises during the 90 s with the boom of computers in educational contexts. It is defined as individuals' general beliefs about their abilites to use computers competently through multiple domains (Hasan, 2006). For Torkzadeh, Chang, \& Demirhan (2006), computer self-efficacy plays an important role in an individual's decision to use a computer and its resources and, therefore, in the disposition to learn other knowledge related to the use of this device.

Computer self-efficacy and students' performance has also been object of study. For example, Compeau \& Higgins (1995) assert that computer self-efficacy exercises significant effects on result expectations and performance in computational scenarios. Peinado \& Ramírez (2014) found that students with a high level of computer self-efficacy exhibit better attitudes and academic achievements than their peers with a low or medium level of computer self-efficacy. According to the foregoing and to the findings of Moos \& Azevedo (2009), behavioral and psychological factors have a positive relationship with computer self-efficacy, which, in turn, positively influences students' learning results in computational environments.

The third field of study, referred to as the field of interest, is self-efficacy in internet-based learning environments. Is defined as the judgements that students make about their ability to organize and execute activities related to the Internet in order to produce the desired results (Eastin \& LaRose, 2000). More recently, Cheng \& Tsai (2011) redefine it as students' expectations and confidence to participate and learn in Web-based environments. Diverse studies assert that the increase in levels of self-efficacy in internet-based learning environments can lead to the development of better cognitive and metacognitive abilites for information searches in a Web-based environment and, in turn, promote students' learning (Tzeng, 2009).

Research into self-efficacy in internet-based learning environments has been more prominent than in the foregoing postulates. In this regard, Tsai et al. (2011) asserts that IS has been linked to: learning processes ( $\mathrm{Lu}$ et al., 2007), learning results (Chu \& Tsai, 2009), anxiety (Ekizoglu \& Ozcinar, 2010), results expectations (Bates \& Khasawneh, 2007), and information searches (Chiou \& Wan, 2007), among others.

Based on the foregoing, it is possible to assert that in the research into the role that individuals' self-efficacy plays when they interact with computational learning environments, this has been researched significantly in recent decades (Tsai et al., 2011). A practical evolution of the concept can be observed, which has allowed researchers to effectively link it as a variable object of study, which, in turn, derived into the establishment of didactic strategies for the design of computational scenarios that take into account students' motivational dimension (López, Hederich, \& Camargo, 2012). Consequently, the present study has gathered and studied 81 research articles published between 2006 and 2015, derived from the fields of study already described, and it performs a bibliometric analysis of the literature in question.

\section{Methodology}

With the purpose of obtaining a scientific production approach to the subject matter of 
self-efficacy and its association with learning in computational environments, a bibliometric study is conducted with descriptive type techniques.

To that end, three databases were chosen, the first two of an international nature, Science Direct and Scopus, and the third of a regional nature and free to access, SciELO. Subsequently, a set of search words was determined in order to obtain a more precise and representative sample of the published papers. The expressions used were "self-efficacy", “computer", "computer-based learning”, "academic self-efficacy", and "Internet-based learning" for the Science Direct and Scopus databases, and the expressions "autoeficacia [self-efficacy]", “autoeficacia académica [academic self-efficacy]", “aprendizaje en línea [onlined learning]", "enseñanza asistida por computador [computer-aided learning]", "educación a distancia [distance learning]", and "Internet”, for SciELO. These expressions were established for the fields of: Title, abstract, and keywords, using as a connector the logic operator "AND". The search was limited to publication dates between the years 2006 and 2015. Additionally, the search was filtered by refereed and published; books, conference papers, dissertations, and other type of documents were not taken into account.

The bibliographical data report was imported into an Excel file. This was debugged by eliminating publication entries repeated two or more times, preferably opting for information obtained from Science Direct, given that the complete texts in PDF files can be found with high-frequency in this database. To obtain the number of citations of each publication, the Google Scholar site was visited. Additionally, the impact factor of the journals where the articles were published were examined. To that end, SCI-mago ${ }^{1}$ information was used to identify the publications metrics based on the SCIMAGO Journal Rank (SJR) ${ }^{2}$. The resulting data matrix considered the fields: article title, publication year, authors, journal name, abstract, keywords, country where the study was conducted, number of citations reported in Google Scholar, participants' identification by level of education and number, research approach, methodological design and type of data, instruments, chosen knowledge area of the study, type of computational scenario used, and references according to American Psychological Association (APA) style.

\section{Bibliometric Study Results}

The initial results showed a total of 142 publications, which were reviewed to establish their relevance and identify duplicate entries. A total of 81 papers that systematically study the subject matter of self-efficacy and its association with learning in computational environments were confirmed. Of this set of articles, 53 were obtained from Science Direct, 19 from Scopus, and 9 from SciELO.

\subsection{General Aspects}

Regarding the origin of the scientific papers, it was found that they proceed from 19 countries. In terms of production by country (Figure 1), the countries that stand out ${ }^{1}$ Accessed on 03/16/2016 retreieved from http://www.scimagojr.com/index.php

${ }^{2}$ SCImago Journal Ranking (SJR indicator) is a measurements of the scientific influence of the specialized journals. 
for exhibiting greater research and productivity in the subject matter are Taiwan, with 23 papers; United States, with 17, and Turkey, with 11. These papers, as a whole, represent $63 \%$ of total papers. Asian countries contribute $49 \%$ of the research in the area of interest, followed by North America, with 21\%; Europe, with 20\%, and, finally, South America, with 10\%.

In relation to the contexts within which the studies are conducted and participants' levels of education, higher education stands out as the context within which the subject matter is studied the most. In Figure 2, a representation of the situation is shown. Indeed, of the 81 articles found, 48 (62\%) refer to applications in universities. With much smaller shares, there are applications in secondary and middle education 12 (15\%), basic primary education $8(10 \%)$, distance education through Internet 7 (9\%), and adult education 3 (4\%) in informal contexts. It is noteworthy to mention that these values do not take into account 3 studies of a documentary nature.

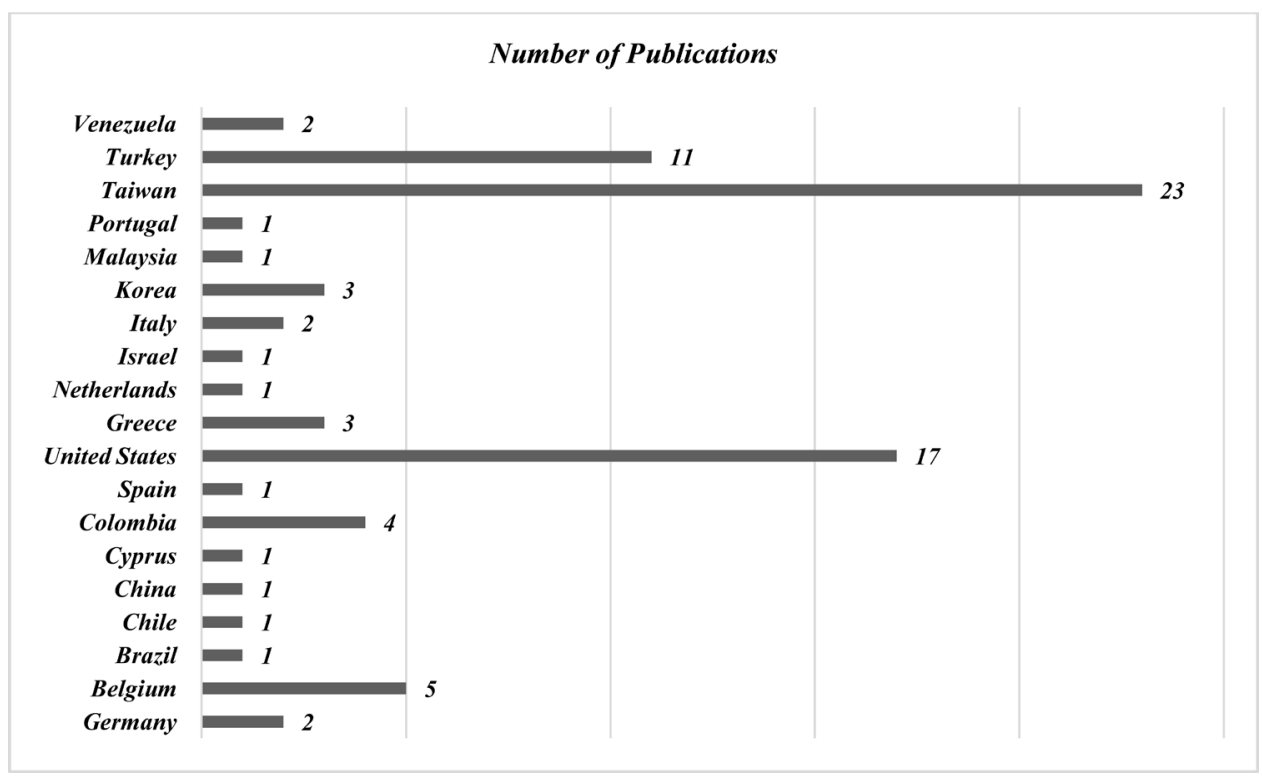

Figure 1. Country of origin of research.

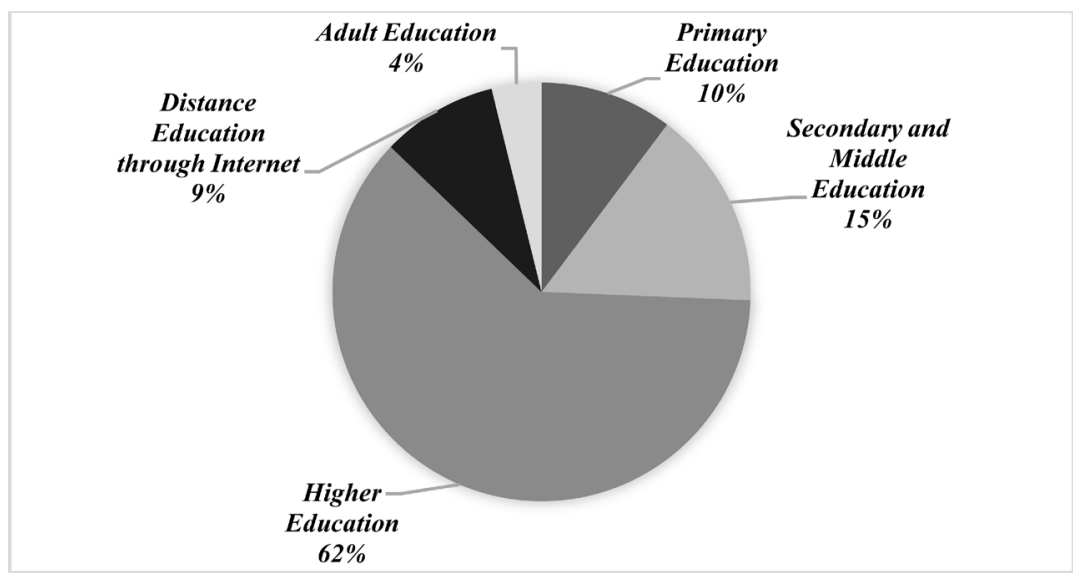

Figure 2. Levels of education. 
Figure 3 shows the distribution of participants only in the context of higher education by discipline. As it can be observed, participants that come from higher education programs that educate educators represent $38 \%$ of the population in this context and, in turn, these represent $22 \%$ of the total of studies on the subject matter. There are also participants from nursing and medicine programs (11\%), engineering (8\%), and psychology (8\%). It is noteworthy to mention that $18 \%$ of the participants come from diverse disciplines, such as social sciences, humanities, and architecture among others.

On the other hand, Figure 4 shows the types of computational environments that researchers use to develop the studies, which are the scenarios with which participants interact. E-learning environments are the most used: courses embedded in Learning Management System (LMS) platforms, mainly Moodle and Blackboard. These are followed by the Internet and to a lesser degree, hypermedia environments.

Figure 5 shows the domains of knowledge that frame the development of research activities, according to the evidence gathered. As it can be observed, the field where most publications converge is Computer Science, with 63\% (digital literacy, Internet,

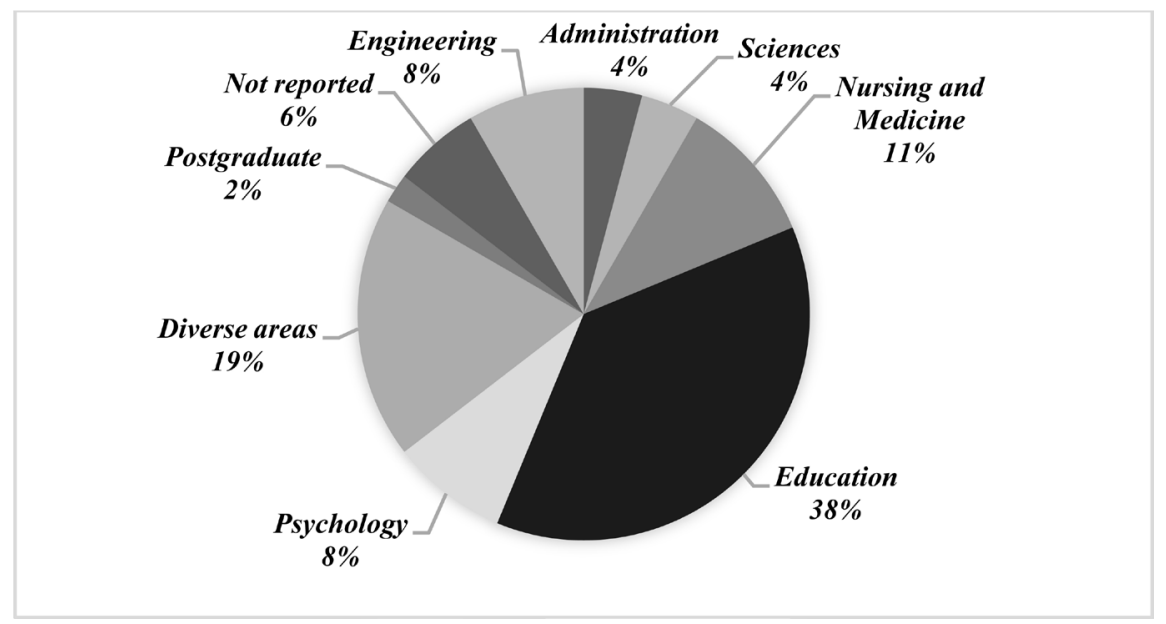

Figure 3. Distribution of higher education participants.

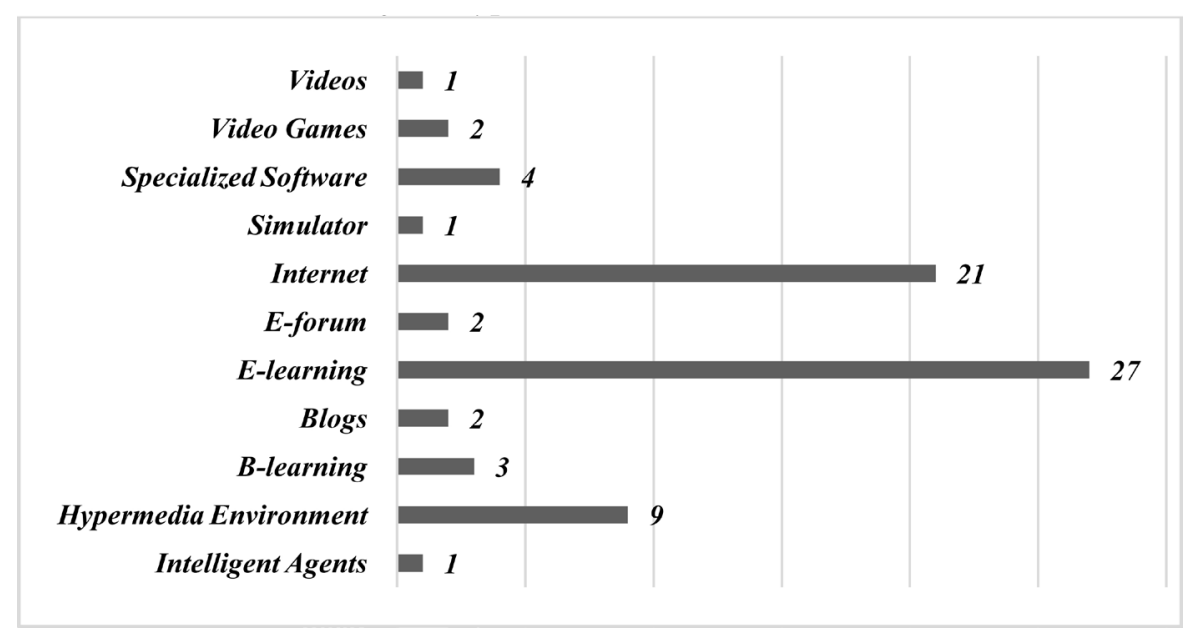

Figure 4. Types of computational environments. 


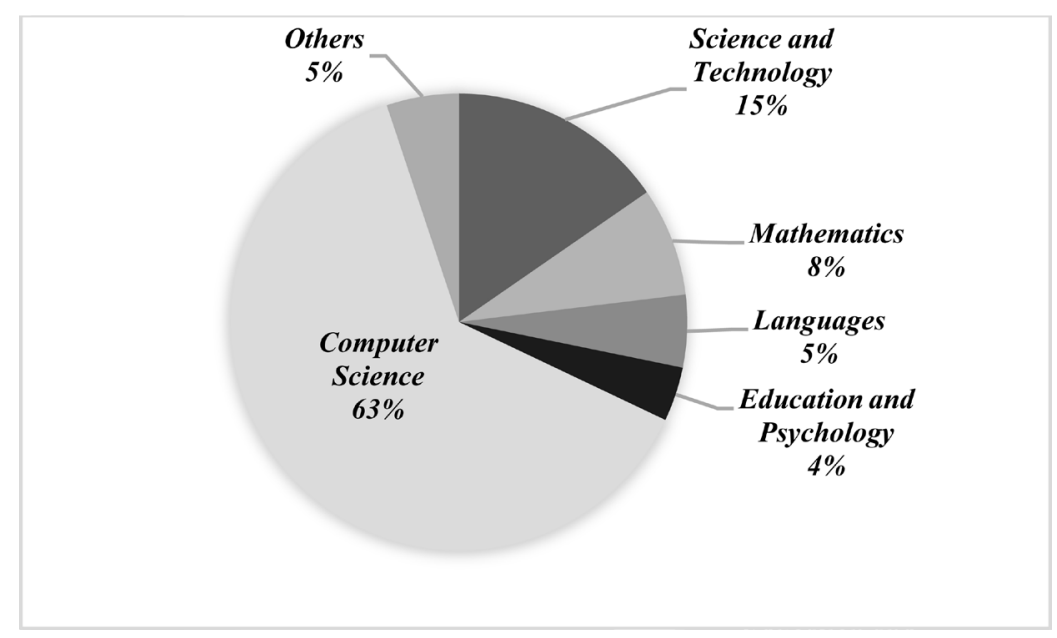

Figure 5. Knowledge areas of study.

Table 1. Production per year in social sciences and humanities journals.

\begin{tabular}{lc}
\hline Year & Number of Articles \\
\hline 2006 & 7 \\
2007 & 5 \\
2008 & 7 \\
2009 & 5 \\
2010 & 13 \\
2011 & 10 \\
2012 & 6 \\
2013 & 10 \\
2014 & 8 \\
2015 & 10 \\
\hline
\end{tabular}

hardware, and software), followed by Science and Technology (15\%), and to a lesser extent Mathematics (8\%), Languages (5\%) and Education and Psychology (4\%).

\subsection{Bibliographical Aspects}

Table 1 shows the number of publications found in this review by year of publication. The year 2010 is the period with the most publications on the subject matter with a total of 13 articles, followed by the years 2011, 2013, and 2015, each one with 10 articles. In contrast, the years 2007 and 2009 have the lowest number of publications: 5 articles per year. An important increase can be observed in the number of publications starting from the year 2010 and up to the year 2015, this period represents $70 \%$ of total papers. An increase can be observed in the number of publications in the last five years as a result of the heightened academic interest in the subject matter of self-efficacy associated with the use of a computer.

Articles on the subject matter located in this study have been published in a total of 31 refereed scientific journals. Table 2 shows the list of the journals' names, the amount 
Table 2. Included journals that have published on self-efficacy associated with the use of a computer in learning situations.

\begin{tabular}{|c|c|c|c|}
\hline Journal Name/Country & $\begin{array}{l}\text { Number of } \\
\text { publications }\end{array}$ & Indexing & $\begin{array}{c}\text { Impact } \\
\text { Factor-SJR } \\
(2014)\end{array}$ \\
\hline Acta Colombiana de Psicología (Colombia) & 1 & A1 & 0.13 \\
\hline American Journal of Distance Education (United Kingdom) & 2 & A2 & 0.34 \\
\hline Children and Youth Services Review (United Kingdom) & 1 & A1 & 0.77 \\
\hline Computers and Education (United Kingdom) & 27 & $\mathrm{~A} 1$ & 2.58 \\
\hline Computers in Human Behavior (United Kingdom) & 11 & A1 & 1.58 \\
\hline Contemporary Educational Psychology (United States) & 1 & $\mathrm{~A} 1$ & 1.99 \\
\hline Educational Technology and Society (United States) & 3 & A1 & 0.92 \\
\hline Evaluation and Program Planning (United Kingdom) & 1 & A2 & 0.47 \\
\hline $\begin{array}{l}\text { International Journal of Human Computer Studies (United } \\
\text { States) }\end{array}$ & 1 & $\mathrm{~A} 2$ & 0.9 \\
\hline Interactive Learning Environments (United Kingdom) & 1 & $\mathrm{~A} 1$ & 0.99 \\
\hline Internet and Higher Education (Netherlands) & 2 & $\mathrm{~A} 1$ & 2.52 \\
\hline Investigación y Postgrado (Venezuela) & 1 & $\mathrm{C}$ & ---- \\
\hline Journal of Computer Assisted Learning (United Kingdom) & 2 & A1 & 2.05 \\
\hline $\begin{array}{l}\text { Journal of Information Technology Education: Research } \\
\text { (United States) }\end{array}$ & 1 & $\mathrm{~A} 2$ & 0.74 \\
\hline Nurse Education Today (United Kingdom) & 2 & $\mathrm{~A} 1$ & 0.73 \\
\hline Pensamiento Psicológico (Colombia) & 1 & A1 & $-\cdots-$ \\
\hline Procedia-Social and Behavioral Sciences (Netherlands) & 7 & $--\cdot--$ & 0.16 \\
\hline Psicología desde el caribe (Colombia) & 1 & $\mathrm{~A} 1$ & $-\cdots$ \\
\hline Teaching and Teacher Education (United Kingdom) & 1 & A1 & 1.77 \\
\hline Transportation Research Part F (United Kingdom) & 1 & A1 & 0.98 \\
\hline Journal of Academic Librarianship (Netherlands) & 1 & A1 & 0.73 \\
\hline Universitas Psychologica (Colombia) & 1 & A1 & 0.26 \\
\hline Educación Química (Mexico) & 1 & A1 & 0.21 \\
\hline Revista Psicologia: Organizações e Trabalho (Brazil) & 1 & $\mathrm{C}$ & $-\cdots-\cdot$ \\
\hline Revista Brasileira de Orientacao Profissional(Brazil) & 1 & $\mathrm{~A} 2$ & 0.21 \\
\hline Revista Colombiana de Educación (Colombia) & 1 & $\mathrm{~A} 2$ & $-\cdots$ \\
\hline $\begin{array}{l}\text { TOJET: The Turkish Online Journal of Educational } \\
\text { Technology (Turkey) }\end{array}$ & 2 & $\mathrm{~B}$ & 0.49 \\
\hline Electronic Library (United Kingdom) & 1 & $\mathrm{~A} 1$ & 0.62 \\
\hline Information \& Management (Netherlands) & 2 & A1 & 1.18 \\
\hline Journal of Educational Computing Research (United States) & 1 & A1 & 0.87 \\
\hline $\begin{array}{l}\text { Cyberpsychology, Behavior, and Social Networking (United } \\
\text { States) }\end{array}$ & 1 & $\mathrm{C}$ & 1.65 \\
\hline
\end{tabular}


of articles published on the subject matter during the period of observation, indexing type according to the 2015 Colombian National System of Indexing and Official Approval of Specialized Journals of Science, Technology, and Innovation (PUBLINDEX) and the impact factor. Among the journals that stand out are two from the United Kingdom, Computers \& Education, with 27 publications on the subject matter, and Computers in Human Behavior, with 11 publications. These journals are the basis of the high productivity in the field of the present study. The rest of the journals have between 1 and 3 publications, with the exception of Procedia-Social and Behavioral Sciences, which has 7 publications.

Table 3 shows the relationship between the number of articles and the number of citations per year. A total of 3317 citations were found during the period of observation, of which 2744 citations correspond to the set of publications yielded by the Science Direct database, 532 correspond to Scopus, and 9 to SciELO. The year 2006 is the period with the largest number of citations, with 744 citations in 7 articles; followed by the year 2010, with 587 citations, and the year 2008, with 554 citations. The year 2015 had the lowest number of citations.

Figure 6 shows the indexes of references per year. This bibliometric indicator is obtained based on the quotient between the number of references and the number of published articles per year. It is an indicator of the use of scientific literature for a specific period of time. As can be observed, the index of references peaked in the year 2006, with a value of 106.3 , followed by the year 2007, with 90.6, and the year 2008, with 79.1. These values are consistent with the time that the articles have been in circulation and available to the academic community.

The number of citations received by each article was obtained through Google Scholar. The range is between 0 and 175 citations. The most cited articles are "The relationship of e-Learner's self-regulatory efficacy and perception of e-Learning environmental quality" by Lee and Lee (2008), with 175 citations; "Computer use and the gender gap: The issue of access, use, motivation, and performance" by Imhof, Vollmeyer, \& Beierlein (2007), with 169 citations; and “University Students' Internet Attitudes and

Table 3. Number of citations per year.

\begin{tabular}{ccc}
\hline Year & Number of articles & Number of citations \\
\hline 2006 & 7 & 744 \\
2007 & 5 & 453 \\
2008 & 7 & 554 \\
2009 & 5 & 260 \\
2010 & 13 & 587 \\
2011 & 10 & 358 \\
2012 & 6 & 173 \\
2013 & 10 & 107 \\
2014 & 8 & 76 \\
2015 & 10 & 5 \\
\hline
\end{tabular}




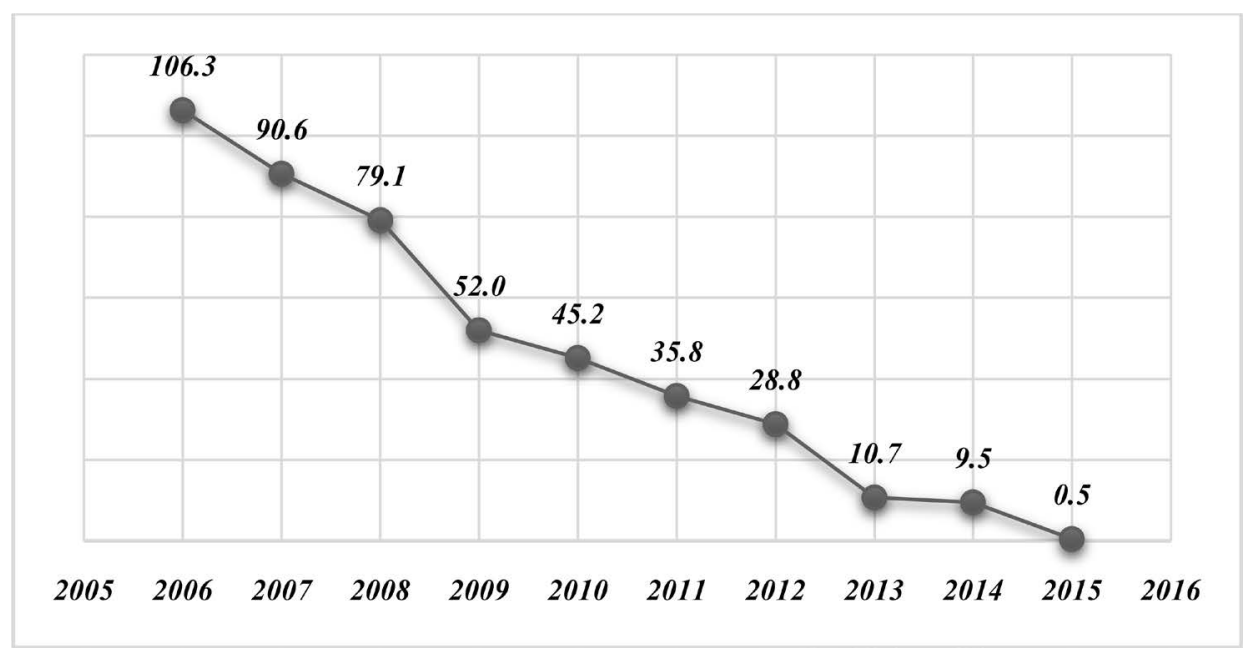

Figure 6. Index of references.

Internet Self-Efficacy: A Study at Three Universities in Taiwan" by Wu \& Tsai (2006), with 159 citations, during the 2006-2015 period.

\subsection{Author Characterization}

In the 81 studies analyzed in this review, 194 authors were identified. Table 4 shows the relationship between widely published authors in the subject matter and the number of articles in which they have participated, whether in an author or coauthor condition. Sixteen authors have participated in two publications; two authors participated in three publications; one author participated in four publications; and one author participated in eleven publications. As can be observed in Table 4, Dr. Chin-Chung Tsai, professor at the Graduate Institute of Digital Learning and Education of the National Taiwan University of Science and Technology, is the most cited author, with 11 publications on the subject matter.

Similarly, Table 5 shows the coauthorship index or signatories/article per period. This Bibliometric indicator refers to the quotient between the total number of signatories (authors) and the number of published articles per year. As can be observed, the authors' mean oscillates between 2.0 authors, corresponding to the years 2009 and 2012, and 2.8 authors, in the years 2007 and 2013.

\section{Research Methods}

With respect to research methods, Table 6 shows those identified. Correlational type studies are predominant, with a frequency of 51 studies (63\%), followed by studies of an experimental nature, with a frequency of 14 studies (17\%), and quasi-experimental nature, with 7 studies (9\%); all of these with a quantitive approach. Descriptive and documentary type studies are used to a lesser extent, each one with three studies, and the exploratory type studies and case study, each one with one study. These results are similar to those reported by Tsai et al., (2011), who in a literature review study during the period between 1999 and 2009 found, in the set of studies analyzed (46 in total), that research with a quantitive and correlational approach prevails. 
Table 4. Authors of publications on the subject matter.

\begin{tabular}{|c|c|}
\hline Author & Number of Articles \\
\hline Chin-Chung Tsai & 11 \\
\hline Omar López-Vargas & 4 \\
\hline Geraldine Clarebout & 3 \\
\hline Jyh-Chong Liang & 3 \\
\hline Chia-Pin Kao & 2 \\
\hline Ching-Chin Chern & 2 \\
\hline Donata Francescato & 2 \\
\hline Hatice Odacı & 2 \\
\hline Houn-Gee Chen & 2 \\
\hline Jan Elen & 2 \\
\hline Jiun-Yu Wu & 2 \\
\hline Li-Yueh Chen & 2 \\
\hline Marina Papastergiou & 2 \\
\hline Norma A. Juarez-Collazo & 2 \\
\hline Regina Juchun Chu & 2 \\
\hline Rita Porcelli & 2 \\
\hline Shih-Chyueh Chuang & 2 \\
\hline Ying-Tien Wu & 2 \\
\hline Yu-Chun Kuo & 2 \\
\hline Anastasia Kitsantas & 2 \\
\hline
\end{tabular}

Table 5. Coauthorship index per year.

\begin{tabular}{lc}
\hline Year & Coauthorship Index \\
\hline 2006 & 2.6 \\
2007 & 2.8 \\
2008 & 2.4 \\
2009 & 2.0 \\
2010 & 2.2 \\
2011 & 2.7 \\
2012 & 2.0 \\
2013 & 2.8 \\
2014 & 2.5 \\
2015 & 2.0 \\
\hline
\end{tabular}


Table 6. Research methods employed.

\begin{tabular}{cc}
\hline Method Employed & Number of Publications \\
\hline Quasi-experiment & 7 \\
Correlational Study & 51 \\
Case Study & 1 \\
Descriptive Study & 3 \\
Documentary Study & 3 \\
Exploratory Study & 2 \\
Experiment & 14 \\
\hline
\end{tabular}

Table 7. Instruments with the highest frequency of use in the studies.

\begin{tabular}{cc}
\hline Instrument Name and Author(s) & Number of Uses \\
\hline CSES (Compeau \& Higgins, 1995) & 4 \\
ISES (Tsai \& Tsai, 2003) & 9 \\
Internet Self-efficacy Scale (Joo, Bong, \& Choi, 2000) & 2 \\
Educational Internet Use Self-efficacy Beliefs Scale (Sahin, 2009) & 2 \\
Escala de Autoeficacia-Internet (Torkzadeh \& Van Dyke, 2001) & 2 \\
Escala Autoeficacia-Internet (Eastin \& LaRose, 2000) & 2 \\
Self-efficacy Subscale of MSLQ (Pintrich, et al. 1991) & 14 \\
Academic Self-efficacy Scale (Jerusalén \& Schwarzer, 1981) & 3 \\
\hline
\end{tabular}

\subsection{Use of Instruments}

In regard to the instruments used in the studies, a significant and important number of scales and questionnaires were found, which are used and elaborated by the authors themselves; in some cases, as information gathering sources. A total of 62 questionnaires to measure self-efficacy were counted, which are characterized for being selfreporting, Likert-type scale, whose purpose is to evaluate participants' perception with respect to their self-efficacy in different domains. Among the latter, those mainly associated with self-efficacy with the use of a computer, with the use of Internet and Web or online learning environments, and academic self-efficacy, were identified.

Table 7 shows the most frequently used instruments in the studies considered. Those that stand out because of their use in research are: the Self-efficacy subscale of the MSLQ (Pintrich, Smith, Garcia, \& McKeachie, 1991), which is used in 14 studies, followed by the Internet Self-efficacy Scale (ISES) and the Web-based Learning Self-Efficacy Scale (WBLSES) (Tsai \& Tsai, 2003), used in 9 studies, and the Computer Self-efficacy Scale (CSES) (Compeau \& Higgins, 1995), used in 4 studies.

\section{Discussion and Conclusion}

The bibliometric study of the published articles on the role of individuals' self-efficacy 
when they interact in computational environments in refereed journals and extracted from the Science Direct, Scopus, and SciELO databases, period 2006-2015, allows evidencing some charactersitics of the research developed globally in this field: its diverse position, methodologically plural, supported in the design and use of different instruments to evaluate self-efficacy, and strongly based on the theoretical constructs elaborated by Bandura $(1986,1997)$. In addition to this study's quantitative results already presented, it was possible to discern qualitative trends, which need to be mentioned in this section.

In the first place, the interest of the subject matter has aroused in other geographical lattitudes is noteworthy. Tsai, Chuang, Liang \& Tsai (2011), in the results of their literature review study, discussed the lack of papers originating in Europe; additionally, no result is reported as proceeding from South America. In contrast, the findings indicate that these data have changed during the last five years: even though Asian countries continue leading the scientific production, the progress made by European and South American countries, which together reported $30 \%$ of total papers analyzed in the present study, is noticeable.

In the second place, a discernable trend is the development of studies with higher education students. Of the 81 analyzed articles, 48 studies were identified as having been developed within universities. The samples' demographic characteristics reveal that university students turn out to be the preferred subjects for these studies. Additionally, it was possible to recognize a favorable trend, in recent years, to mobilize this type of papers towards initial levels of education, such as basic and middle education, which accounted for 20 studies, of which eight were conducted in basic primary education (Aesaert \& Van Braak, 2014; Barak, Ashkar, \& Dori, 2011; Kao \& Tsai, 2009; Kao, Wu, \& Tsai, 2011; López, Sanabria, \& Sanabria, 2014; López \& Triana, 2013; Meluso, Zheng, Spires, \& Lester, 2012; Shank \& Cotten, 2014).

In this regard, a growing interest to analyze the subject matter in students enrolled in Education or Bachelor's programs in higher education was observed. An important group of publications refers to papers conducted in this context. With respect to the latter, research was found that inquires into the beliefs of self-efficacy of pre-service teachers associated with: the use of a computer (Bustos, 2012; Ekizoglu \& Ozcinar, 2010), the use of Internet (Ekizoglu \& Ozcinar, 2010; Gürol \& Akti, 2010; Kaya \& Durmus, 2010; Liang \& Tsai, 2008; Sirakaya, Başarmak, \& Baltaci, 2015), learning in Web environments (Kao \& Tsai, 2009; Kao et al., 2011; Liang \& Tsai, 2008), and ICT teaching (Bustos, 2012), for which a specific instrument was used (Wang, 2004).

In the third place, the finding of a great diversity of instruments (questionnairesscales) used to measure participants' self-efficacy. As shown in Table 7, researchers tend to use reliable and valid instruments in different contexts. Noteworthy, among these, are the scales elaborated by Compeau \& Higgins, 1995; Pintrich et al., 1991; and Tsai \& Tsai, 2003. The former was designed to measure self-efficacy in the use of a computer, the second to measure academic self-efficacy, and the latter to measure self-efficacy in the use of Internet and learning Web environments. Results evidenced 
that these scales are translated and adjusted to contexts where they are applicable and validated for their subsequent use.

The fourth aspect worth mentioning refers to the research methods. The results evidenced a large part of the studies to be of a correlational nature and that use self-reporting surveys and questionnaires as a predominant source of information gathering. These methods are oriented towards identifying what the behavior or what the degree of relationship of the self-efficacy variable is with respect to other educational variables in the same population group. The manner to do this, generally, is through descriptive and correlational studies, which are supported on the application of different statistical tests to approve or reject the proposed hypotheses.

Following this type of studies are the experimental and quasi-experimental studies of a quantitative approach that, in contrast to the foregoing, are characterized by the creation of population groups, whether randomly or previously established, as the case may be. The objective of this type of studies, in most cases, is to verify the effect of the implementation of pedagogical strategies and/or computational scaffolding on other variables involved in educational processes (López, Sanabria et al., 2014; López \& Triana, 2013; López \& Valencia, 2012; Moos \& Azevedo, 2008; Papastergiou, Gerodimos, \& Antoniou, 2011; Plant, Baylor, Doerr, \& Rosenberg-Kima, 2009; Schuyten \& Dekeyser, 2007; Sins, van Joolingen, Savelsbergh, \& van Hout-Wolters, 2008).

Finally, another finding worth emphasizing refers to the type of digital technologies that are used in the studies. As presented in Figure 4, e-learning technologies are the basis for the research and are used to validate an important number of papers related to the subject matter. It is important to highlight the implementation of LMS platforms like Moodle and Blackboard, which currently drive most of the virtual education and distance education programs. The research conducted by Chen \& Tseng, (2012); Lee \& Lee (2008), and Tang \& Tseng (2013) stand out, whose findings indicate the importance of individuals' self-efficacy for successful performance in these educational environments, which in turn, influences other factors that enable better attitudes in students' learning. Hence, self-efficacy constitutes itself as a current topic of interest, which e-learning designers and educators need to take into account in order to put into practice the contributions derived from the research.

Thus, in this spectrum of publications, it is feasible to establish which studies allow gathering sufficient evidence to confront the different theoretical approaches and that may be put into practice, in such a way that teachers and researchers can depend on empirical data that promote the efficient design and development of scenarios and computational scaffolding that contribute to students' cognitive, behavioral, and motivational components and, consequently, to the achievement of better academic performances.

\section{Limitations and Forecasts}

Open to the possibility of having the present study's findings confirmed when extending the analysis towards a broader framework that covers papers published in other in- 
ternational databases, such as Web of Science, EBSCO host Research Data, or ERIC, among others. Additionally, it is important to keep in mind that this study focused exclusively on journal publications in the Social Sciences and Humanities areas.

\section{References}

Aesaert, K., \& Van Braak, J. (2014). Exploring Factors Related to Primary School Pupils' ICT Self-Efficacy: A Multilevel Approach. Computers in Human Behavior, 41, 327-341. https://doi.org/10.1016/j.chb.2014.10.006

Bandura, A. (1986). Social Foundations of Thought and Action: A Social Cognitive Theory. Englewood Cliffs, NJ: Prentice-Hall.

Bandura, A. (1989). Human Agency in Social Cognitive Theory. The American Psychologist, 44, 1175-1184. https://doi.org/10.1037/0003-066X.44.9.1175

Bandura, A. (1997). Theoretical Perspectives. Self-Efficacy: The Exercise of Control (Vol. 50, p. 604).

Barak, M., Ashkar, T., \& Dori, Y. (2011). Learning Science via Animated Movies: Its Effect on Students' Thinking and Motivation. Computers and Education, 56, 839-846. https://doi.org/10.1016/j.compedu.2010.10.025

Bates, R., \& Khasawneh, S. (2007). Self-Efficacy and College Students' Perceptions and Use of Online Learning Systems. Computers in Human Behavior, 23, 175-191. https://doi.org/10.1016/j.chb.2004.04.004

Bustos, C. (2012). Creencias docentes y uso de Nuevas Tecnologías de la Información y Comunicación en profesores de cinco establecimientos chilenos de educación básica y media [Teacher Beliefs and Use of New Technologies of Information and Communication in Professors from Five Elementary and Secondary Chilean Schools]. Universitas Psychologica, 11, 511-522.

Chen, H., \& Tseng, H. (2012). Factors That Influence Acceptance of Web-Based e-Learning Systems for the In-Service Education of Junior High School Teachers in Taiwan. Evaluation and Program Planning, 35, 398-406. https://doi.org/10.1016/j.evalprogplan.2011.11.007

Cheng, K., \& Tsai, C. (2011). An Investigation of Taiwan University Students' Perceptions of Online Academic Help Seeking, and Their Web-Based Learning Self-Efficacy. Internet and Higher Education, 14, 150-157. https://doi.org/10.1016/j.iheduc.2011.04.002

Chiou, W., \& Wan, C. (2007). The Dynamic Change of Self-Efficacy in Information Searching on the Internet: Influence of Valence of Experience and Prior Self-Efficacy. The Journal of Psychology, 141, 589-603. https:/doi.org/10.3200/JRLP.141.6.589-604

Chu, R., \& Tsai, C. (2009). Self-Directed Learning Readiness, Internet Self-Efficacy and Preferences towards Constructivist Internet-Based Learning Environments among Higher-Aged Adults. Journal of Computer Assisted Learning, 25, 489-501. https:/doi.org/10.1111/j.1365-2729.2009.00324.x

Compeau, D., \& Higgins, C. (1995). Computer Self-Efficacy: Development of a Measure and Initial Test. MIS Quarterly, 19, 189-211. https:/doi.org/10.2307/249688

Eastin, M., \& LaRose, R. (2000). Internet Self-Efficacy and the Psychology of the Digital Divide. Journal of Computer-Mediated Communication, 6, 1-18. https:/doi.org/10.1111/j.1083-6101.2000.tb00110.x

Ekizoglu, N., \& Ozcinar, Z. (2010). The Relationship between the Teacher Candidates' Computer and Internet Based Anxiety and Perceived Self-Efficacy. Procedia-Social and Behavioral Sciences, 2, 5881-5890. https:/doi.org/10.1016/j.sbspro.2010.03.962

Girasoli, A., \& Hannafin, R. (2008). Using Asynchronous AV Communication Tools to Increase 
Academic Self-Efficacy. Computers \& Education, 51, 1676-1682.

https:/doi.org/10.1016/j.compedu.2008.04.005

Gürol, A., \& Akti, S. (2010). The Relationship between Pre-Service Teachers' Self-Efficacy and Their Internet Self-Efficacy. Procedia-Social and Behavioral Sciences, 2, 3252-3257.

https:/doi.org/10.1016/j.sbspro.2010.03.497

Hasan, B. (2006). Delineating the Effects of General and System-Specific Computer Self-Efficacy Beliefs on IS Acceptance. Information and Management, 43, 565-571. https:/doi.org/10.1016/j.im.2005.11.005

Jan, S. (2015). The Relationships between Academic Self-Efficacy, Computer Self-Efficacy, Prior Experience, and Satisfaction with Online Learning. American Journal of Distance Education, 29, 30-40. https:/doi.org/10.1080/08923647.2015.994366

Kao, C., \& Tsai, C. (2009). Teachers' Attitudes toward Web-Based Professional Development, with Relation to Internet Self-Efficacy and Beliefs about Web-Based Learning. Computers and Education, 53, 66-73. https:/doi.org/10.1016/j.compedu.2008.12.019

Kao, C., Wu, Y., \& Tsai, C. (2011). Elementary School Teachers' Motivation toward Web-Based Professional Development, and the Relationship with Internet Self-Efficacy and Belief about Web-Based Learning. Teaching and Teacher Education, 27, 406-415. https:/doi.org/10.1016/j.tate.2010.09.010

Kaya, S., \& Durmus, A. (2010). Pre-Service Teachers' Perceived Internet Self-Efficacy and Levels of Internet Use for Research. Procedia-Social and Behavioral Sciences, 2, 4370-4376. https:/doi.org/10.1016/j.sbspro.2010.03.695

Lee, J., \& Lee, W. (2008). The Relationship of e-Learner's Self-Regulatory Efficacy and Perception of E-Learning Environmental Quality. Computers in Human Behavior, 24, 32-47. https:/doi.org/10.1016/j.chb.2006.12.001

Liang, J., \& Tsai, C. (2008). Internet Self-Efficacy and Preferences Toward Constructivist Internet-Based Learning Environments: A Study of Pre-School Teachers in Taiwan. Educational Technology \& Society, 11, 226-237.

López, O., \& Triana, S. (2013). Efecto de un activador computacional de autoeficacia sobre el logro de aprendizaje en estudiantes de diferente estilo cognitivo [Effect of a Self-Efficacy Computational Activator on the Learning Achievement in Students of Different Cognitive Style]. Revista Colombiana de Educación, 64, 225-244. https:/doi.org/10.17227/01203916.64rce225.244

López, O., \& Valencia, N. (2012). Diferencias individuales en el desarrollo de la autoeficacia y el logro académico: El efecto de un andamiaje computacional [Individual Differences in the Development of Self-Efficacy and Academic Achievement: The Effect of a Computational Structure]. Acta Colombiana de Psicología, 15, 29-41.

López, O., Hederich, C., \& Camargo, A. (2012). Logro de aprendizaje en ambientes hipermediales: Andamiaje autorregulador y estilo cognitivo [Academic Achievement in Hypermedia Environments, Scaffolding Self-Regulated Learning and Cognitive Style]. Revista Latinoamericana de Psicología, 44, 13-25.

López, O., Ibáñez, J., \& Chiguasuque, E. (2014). El estilo cognitivo y la fijación de metas de aprendizaje en ambientes computacionales [Cognitive Style and Learning Goals Setting in Computational Environments]. Pensamiento Psicológico, 12, 133-148.

López, O., Sanabria, L., \& Sanabria, M. (2014). Logro de aprendizaje en ambientes computacionales: Autoeficacia, metas y estilo cognitivo [Achievement of Learning in Computer Environments: Self-Efficacy, Goals and Cognitive Style]. Psicología Desde El Caribe, 31, 475-494.

Lu, H., Case, D., Lustria, M. L., Kwon, N., Andrews, J. E., Cavendish, S. E., \& Floyd, B. R. (2007). 
Predictors of Online Information Seeking by International Students When Disaster Strikes Their Countries. Cyber Psychology \& Behavior, 10, 709-712.

https:/doi.org/10.1089/cpb.2007.9965

Meluso, A., Zheng, M., Spires, H., \& Lester, J. (2012). Enhancing 5th Graders' Science Content Knowledge and Self-Efficacy through Game-Based Learning. Computers and Education, 59, 497-504. https:/doi.org/10.1016/j.compedu.2011.12.019

Moos, D., \& Azevedo, R. (2008). Monitoring, Planning, and Self-Efficacy during Learning with Hypermedia: The Impact of Conceptual Scaffolds. Computers in Human Behavior, 24, 16861706. https:/doi.org/10.1016/j.chb.2007.07.001

Moos, D., \& Azevedo, R. (2009). Learning with Computer-Based Learning Environments: A Literature Review of Computer Self-Efficacy. Review of Educational Research, 79, 576-600. https:/doi.org/10.3102/0034654308326083

Odaci, H. (2013). Risk-Taking Behavior and Academic Self-Efficacy as Variables Accounting for Problematic Internet Use in Adolescent University Students. Children and Youth Services Review, 35, 183-187. https:/doi.org/10.1016/j.childyouth.2012.09.011

Papastergiou, M., Gerodimos, V., \& Antoniou, P. (2011). Multimedia Blogging in Physical Education: Effects on Student Knowledge and ICT Self-Efficacy. Computers and Education, 57, 1998-2010. https:/doi.org/10.1016/j.compedu.2011.05.006

Peinado, S., \& Ramírez, J. (2014). El efecto de los estilos de aprendizaje y la autoeficacia computacional sobre el desempeño en el foro electrónico [Effect of Learning Styles and Computational Self-Efficacy in Internet Forum Performance]. Investigación y Postgrado, 25, 145-168.

Pintrich, P., Smith, D., Garcia, T., \& McKeachie, W. (1991). A Manual for the Use of the Motivated Strategies for Learning Questionnaire (MSLQ). Ann Arbor, MI: National Center for Research to Improve Postsecondary Teaching and Learning.

Plant, A., Baylor, A., Doerr, C., \& Rosenberg-Kima, R. (2009). Changing Middle-School Students' Attitudes and Performance Regarding Engineering with Computer-Based Social Models. Computers and Education, 53, 209-215. https:/doi.org/10.1016/j.compedu.2009.01.013

Schunk, D. (1991). Self-Efficacy and Academic Motivation. Educational Psychologist, 26, 207231. https:/doi.org/10.1080/00461520.1991.9653133

Schuyten, G., \& Dekeyser, H. (2007). Preference for Textual Information and Acting on Support Devices in Multiple Representations in a Computer Based Learning Environment for Statistics. Computers in Human Behavior, 23, 2285-2301. https:/doi.org/10.1016/j.chb.2006.03.009

Shank, D., \& Cotten, S. (2014). Does Technology Empower Urban Youth? The Relationship of Technology Use to Self-Efficacy. Computers and Education, 70, 184-193.

https:/doi.org/10.1016/j.compedu.2013.08.018

Sins, P., van Joolingen, W., Savelsbergh, E., \& van Hout-Wolters, B. (2008). Motivation and Performance within a Collaborative Computer-Based Modeling Task: Relations between Students' Achievement Goal Orientation, Self-Efficacy, Cognitive Processing, and Achievement. Contemporary Educational Psychology, 33, 58-77. https:/doi.org/10.1016/j.cedpsych.2006.12.004

Sirakaya, M., Başarmak, U., \& Baltaci, Ö. (2015). Analysis of Teacher Candidates' Educational Internet Self-Efficacy Beliefs in Terms of Various Variables. Procedia-Social and Behavioral Sciences, 174, 3094-3101. https:/doi.org/10.1016/j.sbspro.2015.01.1046

Tang, Y., \& Tseng, H. (2013). Distance Learners' Self-Efficacy and Information Literacy Skills. The Journal of Academic Librarianship, 39, 517-521. https:/doi.org/10.1016/j.acalib.2013.08.008

Torkzadeh, G., Chang, J., \& Demirhan, D. (2006). A Contingency Model of Computer and Internet Self-Efficacy. Information \& Management, 43, 541-550. 
https:/doi.org/10.1016/j.im.2006.02.001

Tsai, C., Chuang, S., Liang, J., \& Tsai, M. (2011). Self-Efficacy in Internet-Based Learning Environments: A Literature Review. Educational Technology and Society, 14, 222-240.

Tsai, M., \& Tsai, C. (2003). Information Searching Strategies in Web-Based Science Learning: The Role of Internet Self-Efficacy. Innovations in Education and Teaching International, 40, 43-50. https:/doi.org/10.1080/1355800032000038822

Tzeng, J. (2009). The Impact of General and Specific Performance and Self-Efficacy on Learning with Computer-Based Concept Mapping. Computers in Human Behavior, 25, 989-996. https:/doi.org/10.1016/j.chb.2009.04.009

Usher, E., \& Pajares, F. (2009). Sources of Self-Efficacy in Mathematics: A Validation Study. Contemporary Educational Psychology, 34, 89-101. https:/doi.org/10.1016/j.cedpsych.2008.09.002

Valencia, N., Huertas, A., \& Baracaldo, P. (2014). Los ambientes virtuales de aprendizaje: Una revisión de publicaciones entre 2003 y 2013, desde la perspectiva de la pedagogía basada en la evidencia [Virtual Learning Environments: Review of Publications between 2003-2013 from the Evidence-Based Pedagogy Perspective]. Revista Colombiana de Educación, 66, 73-102. https:/doi.org/10.17227/01203916.66rce73.102

Wang, L. (2004). Impact of Vicarious Learning Experiences and Goal Setting on Pre-Service Teacher's Self-Efficacy for Technology Integration. Journal of Research on Technology Integration 36, 2360-2363.

Wu, Y., \& Tsai, C. (2006). University Students' Internet Attitudes and Internet Self-Efficacy: A Study at Three Universities in Taiwan. Cyberpsychology \& Behavior, 9, 441-450.

https:/doi.org/10.1089/cpb.2006.9.441

\section{Submit or recommend next manuscript to SCIRP and we will provide best service} for you:

Accepting pre-submission inquiries through Email, Facebook, LinkedIn, Twitter, etc. A wide selection of journals (inclusive of 9 subjects, more than 200 journals)

Providing 24-hour high-quality service

User-friendly online submission system

Fair and swift peer-review system

Efficient typesetting and proofreading procedure

Display of the result of downloads and visits, as well as the number of cited articles

Maximum dissemination of your research work

Submit your manuscript at: http://papersubmission.scirp.org/

Or contact psych@scirp.org 